\title{
Per-oral endoscopic tunneling for restoration of the esophagus (POETRE) in the management of a complete esophageal obstruction
}

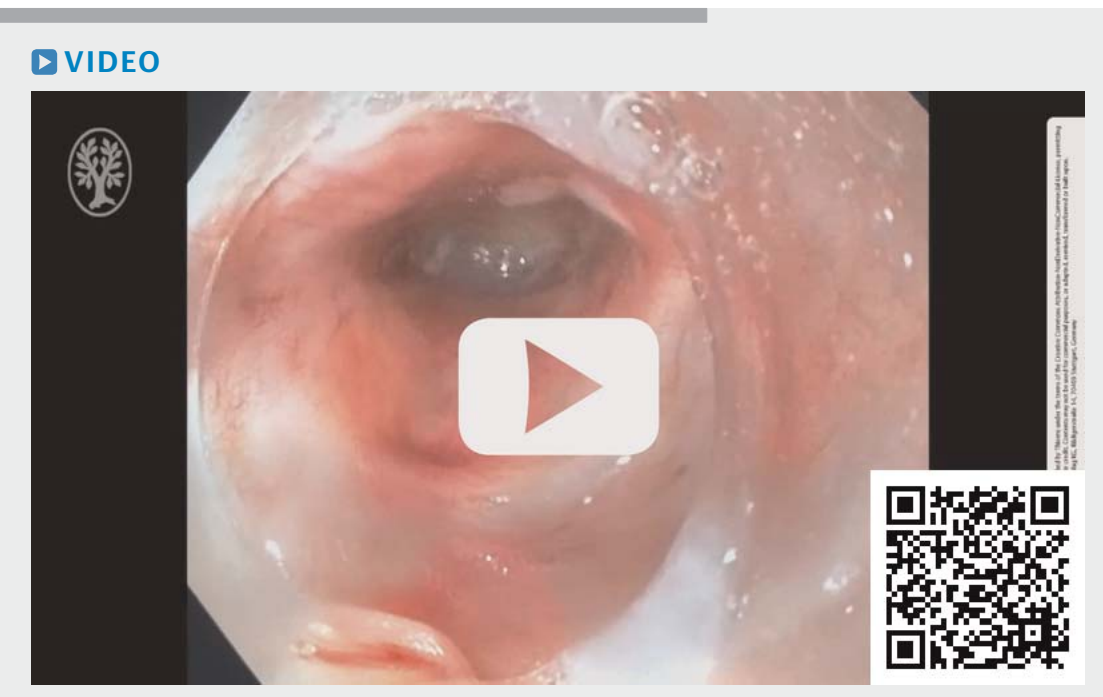

A 54-year-old man with laryngeal carcinoma treated with laryngectomy and adjuvant chemoradiotherapy was referred for management of a long complete post-radiotherapy cervical esophageal obstruction. Previously, he had undergone successive endoscopic dilatations at another institution; due to loss of follow-up, he was now presenting with total aphagia.

After a multidisciplinary evaluation, peroral endoscopic tunneling for restoration of the esophagus (POETRE) was proposed ( $\triangleright$ Video 1 ). A simultaneous dualendoscope procedure was performed (one endoscope via the mouth and another simultaneously inserted retrograde through the percutaneous endoscopic gastrostomy tube tract, after through-the-scope balloon dilation). A

- Video 1 Per-oral Endoscopic Tunneling for Restoration of the Esophagus (POETRE) in the management of a $50 \mathrm{~mm}$ complete esophageal obstruction.

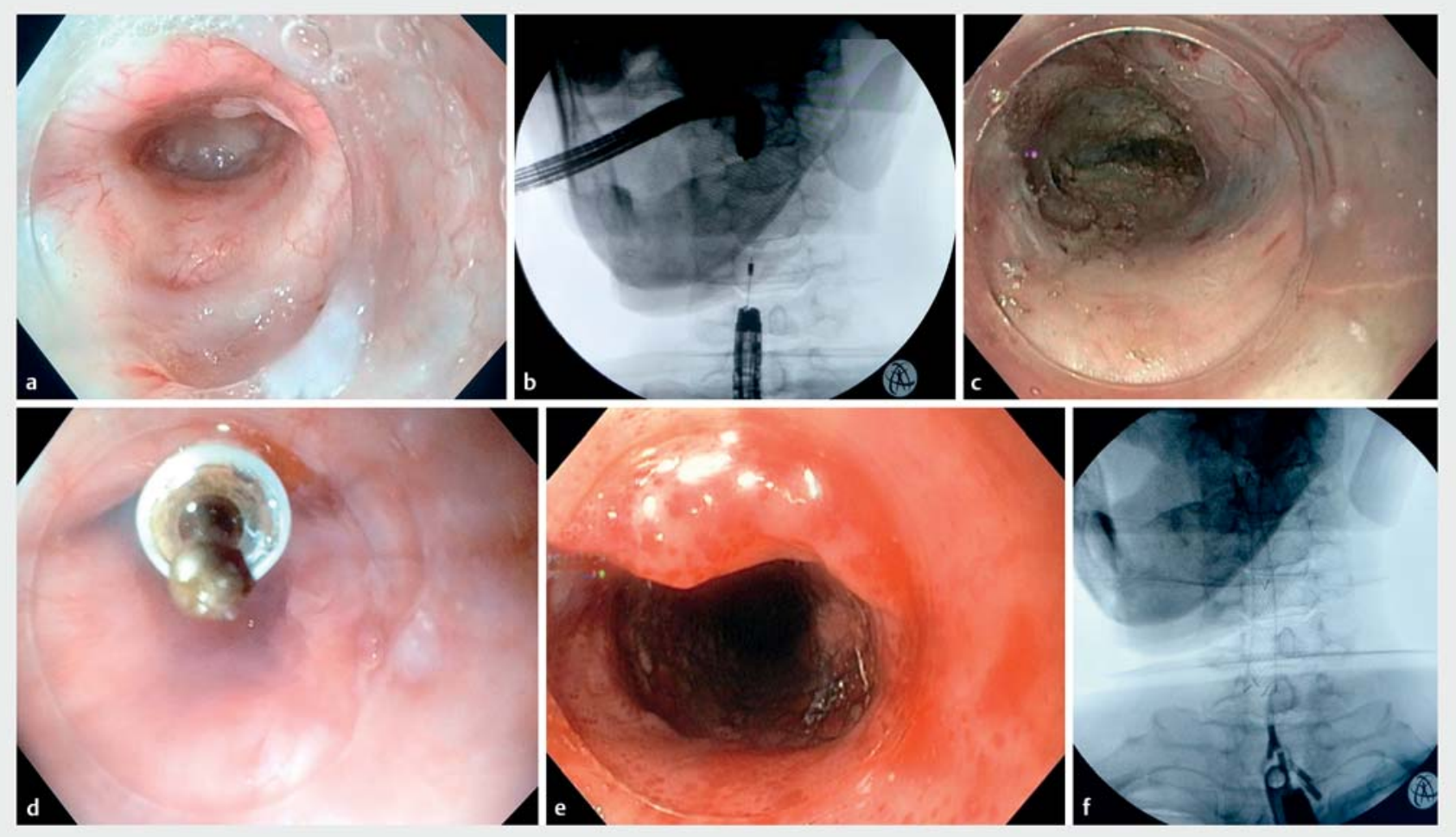

- Fig. 1 a Complete cervical esophageal obstruction (anterograde endoscopy). b Complete cervical esophageal obstruction, seen on fluoroscopy. c The submucosa tunnel created through the fibrotic tissue (retrograde endoscopy). d Anterograde view of the two endoscopes. e A fully covered esophageal stent maintained the new esophageal lumen (retrograde view). f Esophageal stent on fluoroscopy. 
50-mm complete cervical esophageal obstruction was seen (distance between endoscopes on fluoroscopy, $>$ Fig. 1a and $>$ Fig.1b). Because the obstruction was near the esophageal inlet, the retrograde endoscope was advanced up the esophagus and retrograde tunneling was started 5-cm distal to the obstruction, using the FlushKnife $\left(\right.$ Fujifilm ${ }^{\circledR}$ ). When the stricture was encountered, the layered structure of the esophageal wall was completely replaced by fibrotic tissue ( $\mathbf{F i g . 1 c}$ ). This tissue was carefully dissected under antegrade and retrograde endoscopic guidance, together with multi-planar fluoroscopy, to ensure dissection was performed along the long axis of the esophagus (without the usual muscle landmarks that are commonly seen during per-oral endoscopic miotomy). Once the endoscopes were in close proximity, the fibrotic tissue was incised, thereby restoring esophageal continuity and a fully-covered esophageal stent (Niti-S, 12x60 mm) was finally deployed through the created route, maintaining a new esophageal lumen ( Fig.1d, > Fig.1e, > Fig.1f). No complication was encountered and the patient was discharged after 48 hours on a liquid diet.
Two weeks after the procedure, cutaneous exteriorization of the distal extremity of the stent led to its early removal. POETRE was first described in 2014 and published literature on it has been limited to a few case reports or small series $[1,2]$. Despite the late complication, this case demonstrates that POETRE is feasible and should be considered as a therapeutic option in the management of long esophageal obstruction, allowing significant improvement in dysphagia.

\section{Competing interests}

The authors declare that they have no conflict of interest.

The authors

Catarina Félix ${ }^{1}$, Pedro Barreiro ${ }^{1}$, José Rodrigues Azevedo ${ }^{1}$, Luis Maia ${ }^{2}$, Ricardo Küttner-Magalhães ${ }^{2}$, Isabel Pedroto², Cristina Chagas ${ }^{1}$

1 Centro Hospitalar de Lisboa Ocidental ETE Gastroenterology, Lisbon, Portugal

2 Centro Hospitalar do Porto Gastroenterology, Porto, Portugal
Corresponding author

\section{Catarina Félix}

Centro Hospitalar de Lisboa Ocidental EPE Gastroenterology, Rua da Junqueira 126

Lisboa 1449-005, Portugal

Fax: +00351210431000

sfelixcatarina@gmail.com

\section{References}

[1] Wagh M, Yang D, Draganov P et al. Per-oral endoscopic tunneling for restoration of the esophagus (POETRE). Gastrointest Endosc 2014; 80: 330

[2] Wagh M, Draganov P. Per-oral endoscopic tunneling for restoration of the esophagus: a novel endoscopic submucosal dissection technique for therapy of complete esophageal obstruction. Gastrointest Endosc 2017; 85: 722-727

\section{Bibliography}

Endosc Int Open 2021; 09: E1084-E1085

DOI 10.1055/a-1463-3059

ISSN 2364-3722

(C) 2021. The Author(s).

This is an open access article published by Thieme under the terms of the Creative Commons Attribution-NonDerivativeNonCommercial License, permitting copying and reproduction so long as the original work is given appropriate credit. Contents may not be used for commercial purposes, or adapted, remixed, transformed or built upon. (https:// creativecommons.org/licenses/by-nc-nd/4.0/) Georg Thieme Verlag KG, Rüdigerstraße 14, 70469 Stuttgart, Germany 